\title{
The hyperimmunoglobulin E syndrome - clinical manifestation diversity in primary immune deficiency
}

\author{
Aleksandra Szczawinska-Poplonyk ${ }^{1 *}$, Zdzislawa Kycler', Barbara Pietrucha², Edyta Heropolitanska-Pliszka², \\ Anna Breborowicz ${ }^{1}$ and Karolina Gerreth ${ }^{3}$
}

\begin{abstract}
The hyper-IgE syndromes are rare, complex primary immunodeficiencies characterized by clinical manifestation diversity, by particular susceptibility to staphylococcal and mycotic infections as well as by a heterogeneous genetic origin. Two distinct entities - the classical hyper-lgE syndrome which is inherited in an autosomal dominant pattern and the autosomal recessive hyper-lgE syndrome have been recognized. The autosomal dominant hyperIgE syndrome is associated with a cluster of facial, dental, skeletal, and connective tissue abnormalities which are not observable in the recessive type. In the majority of affected patients with autosomal dominant hyper-lgE syndrome a mutation in the signal transducer and the activator of the transcription 3 gene has been identified, leading to an impaired Th17 cells differentiation and to a downregulation of an antimicrobial response. A mutation in the dedicator of the cytokinesis 8 gene has been identified as the cause of many cases with autosomal recessive hyper-lgE syndrome and, in one patient, a mutation in tyrosine kinase 2 gene has been demonstrated. In this paper, the authors provide a review of the clinical manifestations in the hyper-lgE syndromes with particular emphasis on the diversity of their phenotypic expression and present current diagnostic guidelines for these diseases.
\end{abstract}

\section{Introduction}

The hyper-IgE syndrome (HIES) was first described in 1966 by Davis, Wedgwood and Schaller [1]; the authors perceived the similarity of severe dermatitis associated with "cold" abscesses with the disease attributed to the prophet Job and hence designated it "Job's Syndrome". In 1972, Buckley and colleagues reported infectious complications in two children who presented with severe chronic dermatitis, coarse faces, and an increased concentration of serum immunoglobulin E; hence these manifestations were termed "Buckley's Syndrome" [2]. Further investigations revealed that increased IgE concentrations and defective neutrophil chemotaxis [3] are recognized in Job's syndrome as well as in Buckley's syndrome, being the same disease entity. In the 1970s, a manifestation of the immune defect in HIES resulted in

\footnotetext{
* Correspondence: ola@malwa.com.pl

'Department of Pediatric Pneumonology, Allergology and Clinical Immunology, Poznan University of Medical Sciences, 27/33 Szpitalna Street, 60-572 Poznan, Poland

Full list of author information is available at the end of the article
}

its inclusion in the group of primary immunodeficiency diseases by Hill et al [4], and the term "Hyper-IgE Recurrent Infection Syndrome" (HIERIS) as proposed by Buckley was also accepted [5]. Extensive reviews of the syndrome were presented in 2000 by Erlewyne-Lajeunesse [6] and in 2005 by Grimbacher and colleagues [7]; furthermore, discussions on the disease chaired by Freeman and Holland have been recently published $[8,9]$.

Although the first data concerning the prevalence of hyper-IgE syndrome referred only to the Caucasian race, further reports indicate its occurence among the Asian and African populations [10,11]; the syndrome occurs in equal frequency among males and females.

Several manifestations of the hyper-IgE syndrome consist of a clinical symptomatology of related diseases, leading to diagnostic difficulties, particularly in young patients and in atypical less severe cases [12] and the diagnosis of pediatric hyper-IgE syndrome is a compilation of symptoms expressed in the later years of patient's life [7].

\section{Ciomed Central}


The hyper-IgE syndrome is a complex immune deficiency with diverse clinical manifestations and heterogeneous genetic origins [13]. Recent studies have demonstrated that hypomorphic mutations in the signal transducer and the activator of transcription 3 (STAT3) gene result in the classical multisystemic, autosomal dominant form of HIES, associated with facial, dental, skeletal, and connective tissue abnormalities [14-16]. A STAT3 mutation results in a defective multiple cytokine signal transduction, including interleukin (IL)-6 and IL22, leading to impaired Th17 function and thus explaining the susceptibility to infections in HIES.

In 2004 Renner et al [17] reported an autosomal recessive form of the hyper-IgE syndrome, sharing common features with autosomal dominant HIES, such as hyperimmunoglobulinemia E, susceptibility to staphylococcal infections and cutaneous lesions. However, a different infection profile, a high rate of neurological complications, as well as frequently reported autoimmunity and malignancy, suggest a distinct disease entity. Initially, in a single patient with autosomal recessive HIES, a null mutation in the tyrosine kinase 2 (TYK2) gene was identified. The Tyk2 deficiency is responsible for both innate and adaptive impaired immune responses due to defective cytokine signal transduction pathways which depend on interferon (IFN)- $\alpha$, IL-6, IL-10, IL-12, and IL-23 [18]. In many, although not all cases of autosomal recessive HIES, homozygous mutations of dedicator of cytokinesis gene (DOCK 8$)$ has been demonstrated, leading to the disruptive production of a protein involved in the regulation of the actin skeleton [19].

\section{Clinical presentation}

\section{Autosomal dominant HIES}

The clinical triad of symptoms found generally in $75 \%$ of all cases of AD-HIES and in $85 \%$ of patients over 8 years old includes: 1) recurrent staphylococcal abscesses, 2) recurrent airway infections, 3) increased concentration of immunoglobulin E in serum [7]. It has been stressed in the literature that neonatal rash is typically the first clinical manifestation of the hyper-IgE syndrome [20,21]. Interestingly, although chronic dermatitis in the hyper-IgE syndrome is traditionally described as eczema, it is doubtful if this rash really presents as atopic dermatitis [22-24], particularly given that skin biopsies reveal eosinophilic infiltration related to that observed in eosinophilic folliculitis [25]. Skin infections also occur frequently - furunculosis and cellulitis may be observed early on in infancy. "Cold" abscesses, typically observed in patients who are not on antibiotic prophylaxis, are pathognomonic for the hyper-IgE syndrome, but are not necessary for a definitive diagnosis [26,27]. Severe recurrent respiratory infections are usually caused by Staphylococcus aureus, including MRSA [28] and, less frequently, by Haemophilus influenzae and Streptococcus pneumoniae. Pneumonias are typically complicated by lung abscesses [29], bronchiectases, bronchopleural fistulas and the formation of pneumatocele [6,30] (Figure 1). These bronchopulmonary lesions are predisposing factors for colonization by opportunistic microorganisms such as Pseudomonas aeruginosa and Aspergillus fumigatus. The latter can lead not only to invasive aspergillosis requiring intensive therapy, but also to the formation of aspergilloma (Figure 2). Pulmonary sequelae lead invariably to the development of chronic respiratory insufficiency and are the main cause of mortality in HIES. Hemoptysis complicating lung abscess and cystic lung disease are the next common cause of death in HIES reported by Freman et al [31]. Upper airway infections manifest as paranasal sinusitis, exsudative otitis media [32], otitis externa and mastoiditis. In approximately $80 \%$ of all cases, mycotic infections of the skin and mucous membranes with Candida albicans and other fungal strains may coexist [7]. There are also reports concerning Pneumocystis jiroveci infection $[33,34]$, cryptococcosis [35,36], histoplasmosis [37-39], disseminated pulmonary candidiasis [40], Mycobacterium intracellulare and Nocardia infection [12], as well as post-BCG vaccination complications [12,41,42]. In the autosomal dominant form of hyper-IgE syndrome, infections with herpes simplex virus are relatively infrequent [43].

In the majority of affected individuals, characteristic constitutional features are noticeable, such as a coarse face, rough skin, deep-set eyes, a prominent forehead, prognathism (Figure 3), thick lower lip and auricles, a wide nose and increased interalar distance [1,2,34,44,45]. There are also reports concerning mid-face anomalies, an arched palate [34] and a rare malformation - craniosynostosis [46-48]. Characteristic oral and dental manifestations occurring in HIES include the delayed loss of primary teeth, which occurred in $71 \%$ of children over the age of eight years in the study by Grimbacher et al [34], the abnormal development of permanent teeth $[34,49]$, severe dental caries with periapical abscesses formation [50] (Figure 4) and periodontitis [51].

Recurrent pathological bone fractures reflecting the multisystemic involvement in the hyper-IgE syndrome are noted in more than $50 \%$ of patients [7]. Typically, long bones are affected [52], as well as ribs, and, less frequently, the vertebral column may also be involved [34]; these fractures occur frequently as a result of minor injuries. Brestel et al [53] described a pediatric HIES case displayng a rare association with osteogenesis imperfecta tarda. In the group of six patients in whom osteopenia was revealed initially using radiology [54] and subsequently by photon absorptiometry [55], three 


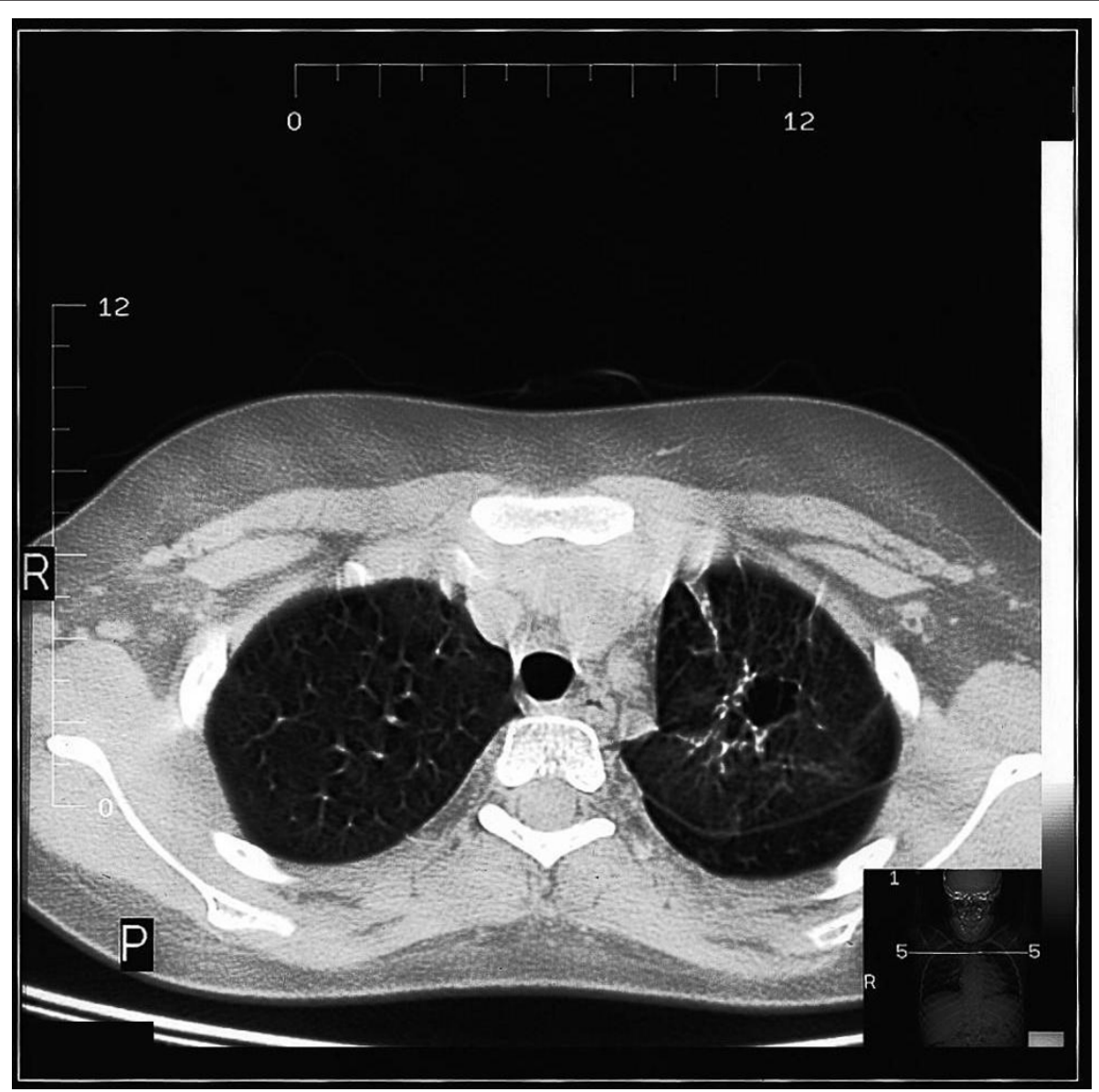

Figure 1 Fine nodules, interstitial infiltrations and a cystic lesion on chest high-resolution computed tomography (HRCT) in a child with HIES.

of them experienced pathological bone fractures. Interestingly, decreased bone mineral density is not a predisposing factor for the pathological fractures. Grimbacher et al [34] showed diminished bone density in a group of five out of nine patients, in whom densitometry was carried out, yet pathological bone fractures occurred in two patients with abnormal results of this examination and in three patients with normal bone mineral density. It has been suggested that osteopenia may result from excessive bone resorption caused by monocytes and activity of prostaglandin E2 [55]; moreover, cytokine profile in the hyper-IgE syndrome influences bone resorption, similar to women in the postmenopausal period [56]. Minegishi et al demonstrated that osteoclasts from HIES patients with STAT3 mutations show higher bone resorption activity compared with those from control subjects [57]. More than $60 \%$ of affected individuals present with scoliosis of varying degrees of severity and of different origin. This may be a result of different longitudinal dimension of the lower limbs, of thoracotomy for the purpose of removing pneumatocele, and of vertebral column anomalies [7], which, together with joint hyperextensibility, are another part of the hyper-IgE puzzle [46-48].

In patients with HIES, ocular complications were noted as well, including extensive xanthelasmas [58], giant chalasias [59,60], undefined eyelid nodules [61], strabismus [62], and retinal detachment with complicated cataracts [63].

The hyper-IgE syndrome brings about an increased risk of autoimmune diseases, among them systemic lupus erythemathosus [64-66], dermatomyositis [67], and membranoproliferative glomerulonephritis [68].

An increased incidence of lymphoproliferative disorders has also been noted, particularly of non-Hodgkin lymphomas [58,69-72] and of Hodgkin disease [73,74]. Oztop and colleagues diagnosed pulmonary adenocarcinoma in a patient with HIES [75].

Ling et al [76] reported coronary artery aneurysms and ectasias identified with cardiac catheterization in two patients with HIES. Subsequently, a review on the vascular features of both autosomal dominant, sporadic 


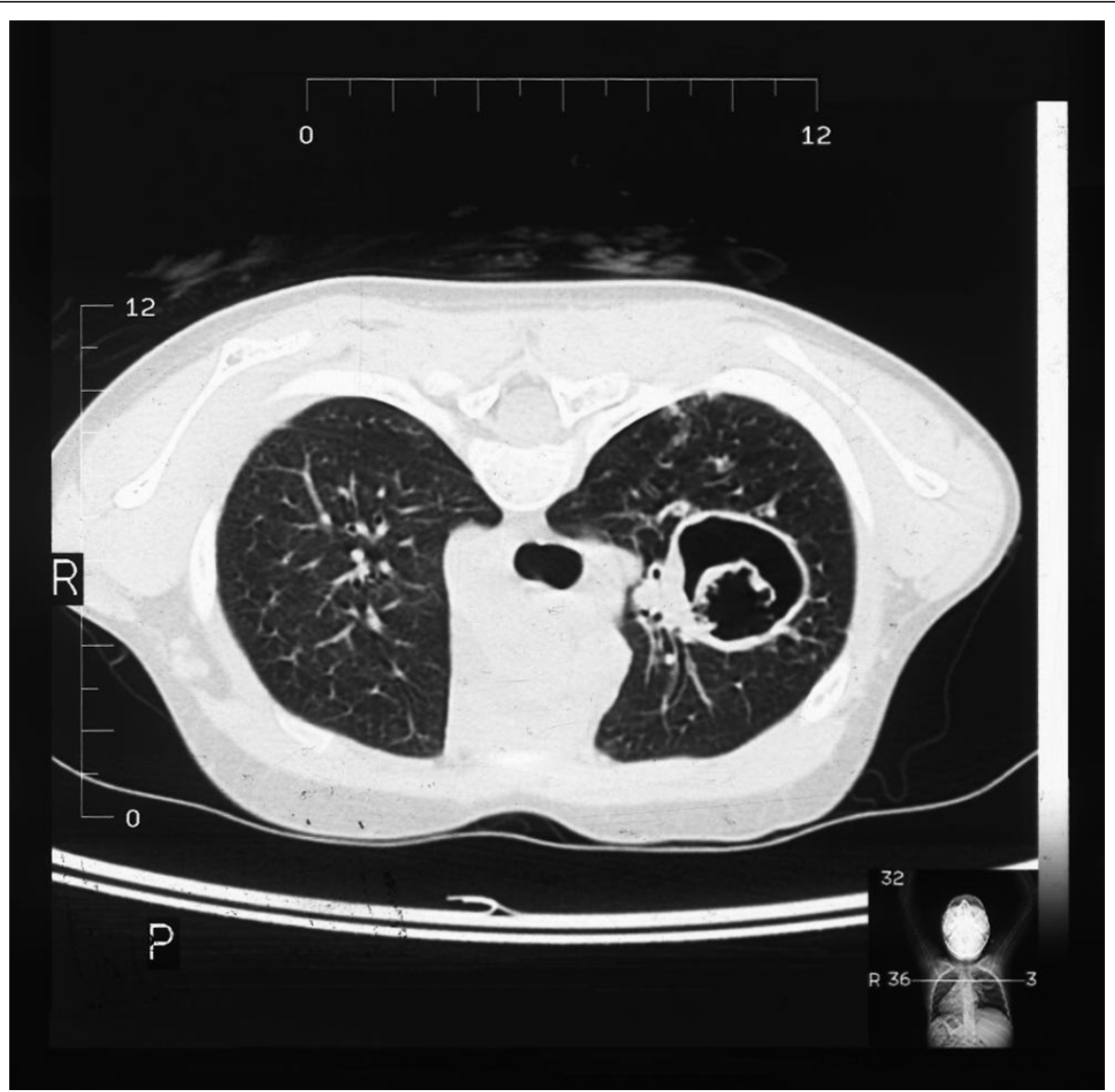

Figure 2 High-resolution computed tomography of the chest in a child with HIES, showing aspergilloma in a postinflammatory cavity

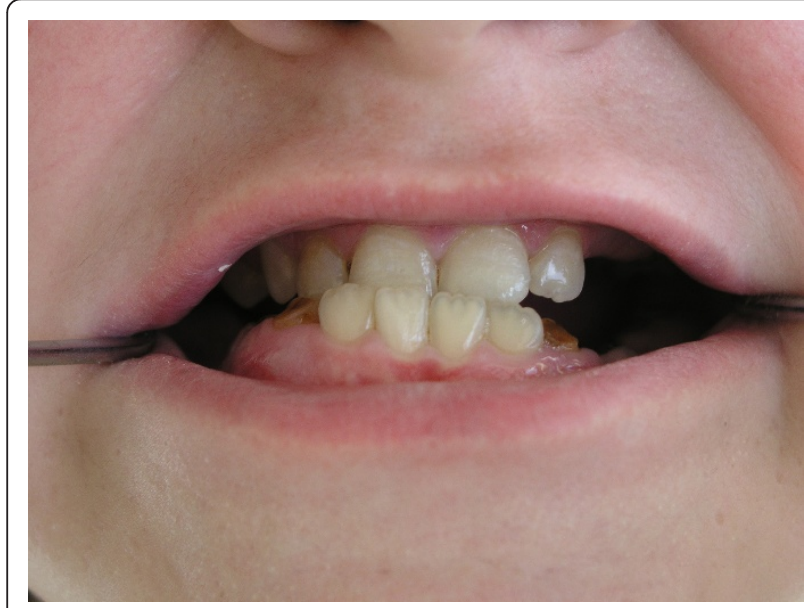

Figure 3 Prognathism in a child with HIES

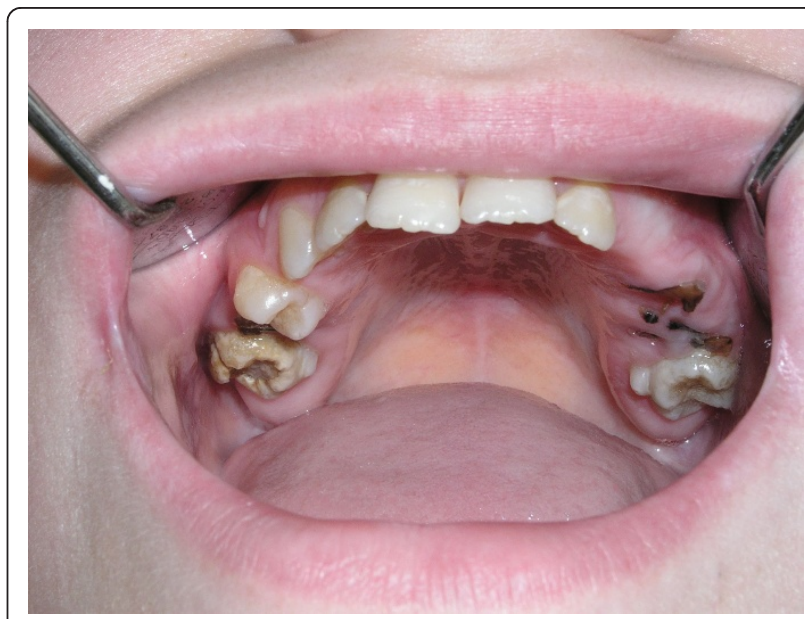

Figure 4 Maxillary teeth with severely damaged primary teeth due to caries as well as carious cavities within permanent dentition in a child with HIES 
Table 1 Scoring System with Clinical and Laboratory Tests for Related Individuals with HIES

\begin{tabular}{|c|c|c|c|c|c|c|c|c|c|c|}
\hline \multirow[t]{2}{*}{ CLINICAL FINDINGS } & \multicolumn{10}{|c|}{ points } \\
\hline & 0 & 1 & 2 & 3 & 4 & 5 & 6 & 7 & 8 & 10 \\
\hline $\begin{array}{c}\text { Highest serum-IgE level } \\
(\mathrm{IU} / \mathrm{ml}) \\
{[\text { Normal }<130 \mathrm{IU} / \mathrm{ml}]}\end{array}$ & $<200$ & $200-500$ & & & $501-1000$ & & & & $1001-2000$ & $>2000$ \\
\hline Skin abscesses & None & & $1-2$ & & $3-4$ & & & & $>4$ & \\
\hline $\begin{array}{c}\text { Pneumonia (episodes over } \\
\text { lifetime) }\end{array}$ & None & & 1 & & 2 & & 3 & & $>3$ & \\
\hline Parenchymal lung anomalies & Absent & & & & & & Bronchiectasis & & Pneumatocele & \\
\hline Retained primary teeth & None & 1 & 2 & & 3 & & & & $>3$ & \\
\hline $\begin{array}{l}\text { Scoliosis, maximum } \\
\text { curvature }\end{array}$ & $<10^{\circ}$ & & $10-14^{0}$ & & $15-20^{\circ}$ & & & & $>20^{\circ}$ & \\
\hline Fractures with minor trauma & None & & & & $1-2$ & & & & $>2$ & \\
\hline $\begin{array}{l}\text { Highest eosinophil count } \\
\text { (cells/ } / \mu \mathrm{l}) \\
\begin{aligned} {[700 / \mu \mathrm{l}=} & 1 \mathrm{SD}, 800 / \mu \mathrm{l}= \\
& 2 \mathrm{SD}]\end{aligned}\end{array}$ & $<700$ & & & $700-800$ & & & $>800$ & & & \\
\hline Characteristic face & Absent & & $\begin{array}{l}\text { Mildly } \\
\text { present }\end{array}$ & & & Present & & & & \\
\hline $\begin{array}{l}\text { Midline anomaly (cleft } \\
\text { palate, cleft tongue, } \\
\text { hemivertebrae, other } \\
\text { vertebral anomaly) }\end{array}$ & Absent & & & & & Present & & & & \\
\hline Newborn rash & Absent & & & & Present & & & & & \\
\hline Eczema (worst stage) & Absent & Mild & Moderate & & Severe & & & & & \\
\hline $\begin{array}{l}\text { Upper respiratory infections } \\
\text { per year }\end{array}$ & $1-2$ & 3 & $4-6$ & & $>6$ & & & & & \\
\hline Candidiasis & None & Oral & Fingernails & & Systemic & & & & & \\
\hline Other serious infections & None & & & & Severe & & & & & \\
\hline Fatal infection & Absent & & & & Present & & & & & \\
\hline Hyperextensibility & Absent & & & & Present & & & & & \\
\hline Lymphoma & Absent & & & & Present & & & & & \\
\hline Increased nasal width & $<1 \mathrm{SD}$ & $1-2 S D$ & & $>2 \mathrm{SD}$ & & & & & & \\
\hline High palate & Absent & & Present & & & & & & & \\
\hline Young-age correction & $>5$ years & & & $2-5$ years & & $\begin{array}{l}1-2 \\
\text { years }\end{array}$ & & $\begin{array}{l}\leq 1 \\
\text { year }\end{array}$ & & \\
\hline
\end{tabular}

and recessive form of the hyper-IgE syndrome was carried out by Yavuz et al [77]. In AD-HIES patients coronary and aortic aneurysms, thrombosis of the cerebellar artery and congenital patent ductus venosus have been identified. In the report by Freeman et al [78] coronary artery tortuosity or dilation occurred in $70 \%$, with aneurysms present in 37\% of STAT3 mutated HIES patients, suggesting that STAT3 may play an integral role in vascular remodeling.

\section{Autosomal recessive HIES}

Patients affected with AR-HIES associated with DOCK8 deficiency share certain clinical features with autosomal dominant HIES, such as newborn rash, eczema and recurrent upper and lower respiratory tract infections. Most of the affected patients reported by Zhang et al $[79,80]$ suffer from recurrent otitis media, mastoiditis, sinusitis, pneumonias or bronchitis with bronchiectasis. However, parenchymal lung abnormalities, including pneumatocele formation have not been observed. Recovered pulmonary pathogens include Streptococcus pneumoniae, Haemophilus influenzae, Pneumocystis jiroveci, adenovirus and respiratory syncytial virus. Mortality is high at a young age in AR-HIES with sepsis, more frequent than in AD-HIES [9]. Furthermore, in contrast to $\mathrm{AD}-\mathrm{HIES}$, in autosomal recessive form of the syndrome, a predisposition to severe fungal and viral cutaneous infections occurs with herpes simplex and herpes zoster, molluscum contagiosum and human papillomavirus [80]. An early onset of malignancies, including cancers related to cutaneous viral infections are an important cause of death, suggesting impaired tumor surveillance. In five pediatric patients out of six recorded AR-HIES individuals, aortic and cerebral aneurysms, underperfusion of 
large arteries and occlusion of small cerebral vessels, variations in the caliber of the basal cerebral arteries, as well as leucocytoclastic vasculitis were diagnosed [77]. Central nervous system (CNS) sequelae, in some patients due to CNS vasculitis, such as facial paralysis, hemiplegia, ischemic infarction, and subarachnoid hemorrhages are common and contribute to high mortality. Neither skeletal abnormalities, pathological bone fractures, dental disorders, nor characteristic facial features occur in this type of HIES.

\section{Laboratory Findings}

\section{Autosomal dominant HIES}

A hallmark of the syndrome is an increased concentration of immunoglobulin $\mathrm{E}$ in the serum, exceeding 2000 $\mathrm{U} / \mathrm{ml}$, frequently higher than $5000 \mathrm{U} / \mathrm{ml}$, and in single cases even exceeding $100000 \mathrm{U} / \mathrm{ml}[5,7,34]$. A value of $2000 \mathrm{U} / \mathrm{ml}$ is considered to be the cut-off point, which has proved helpful in establishing a definitive diagnosis of the syndrome [6]. Nevertheless, not in all patients, particularly in infants, are these criteria fulfilled; although characteristic concentration of IgE may be expected in the third decade of life or even later. Typically in adulthood, in a subset of patients IgE levels may decrease with age and may fall within a normal range in about $20 \%$ of cases [34]. Interestingly, the severity of infectious complications in patients with hyper-IgE syndrome do not correlate with immunoglobulin E concentration in the serum. Muhammed [81] reported on two HIES pediatric patients presenting with recurrent cutaneous lesions, severe respiratory infections and moderately elevated levels of serum IgE $(420 \mathrm{U} / \mathrm{ml}$ and $564 \mathrm{U} /$ $\mathrm{ml})$. This further supports the view that if other features of HIES are present, a normal IgE level should not exclude the presence of HIES in older children. Concentrations of other main classes of immunoglobulins remain normal in the majority of cases. Usually blood eosinophilia coexists, wavering within values at least 2 SD above the normal range (typically higher than 700 cells/microliter) $[7,22]$, not correlating with either the IgE concentration in the serum or the incidence of infectious complications.

In the serum, the presence of specific antistaphylococcal and anticandidal IgE antibodies may be revealed $[82,83]$; moreover, the increase of antigen specific antibodies may precede the first symptoms of infection [84]. However, the increased concentration of antigen specific antibodies may also be noted in patients suffering from atopic dermatitis, rendering the limitation of this test in the diagnosis of the hyper-IgE syndrome [85].

Heterogeneous disorders of the immune system have variably been described in HIES patients, including impaired production of interferon gamma by $\mathrm{T}$ cells, defective $\mathrm{T}$ helper 1 (Th1)-dependent cytokine response, a skewed Th1/Th2 cell ratio, a diminished memory Tcell populations, decreased delayed-type hypersensitivity responses, an impaired response of lymph cells to antigenic and alloantigenic stimulation [86], as well as a defective neutrophil chemotaxis [3]. However, these immunological abnormalities do not explain the unique susceptibility to particular infections seen in HIES.

In 2008, Milner and colleagues [87] demonstrated that $\mathrm{T}$ cells in subjects with AD-HIES failed to produce interleukin (IL)-17 (but not interferon gamma) after mitogenic stimulation with staphylococcal enterotoxin B or after antigenic stimulation with Candida albicans or streptokinase. Purified naïve T cells were unable to differentiate into IL-17 producing the T helper (Th17) cells in vitro and had a lower expression of the retinoidrelated orphan receptor (ROR)- $\gamma \mathrm{t}$, which is consistent with the crucial role of STAT3 signaling in the generation of Th17 cells. These Th17 cells have emerged as an important subset of helper $\mathrm{T}$ cells being critical in the clearance of fungal and extracellular bacterial infections. The Th17 cytokines, IL-17 (IL-17A) and IL-17F form biologically active homo- or heterodimers. Il-17 initiates nuclear factor kappa B $(\mathrm{NF}-\kappa \mathrm{B})$ activation, leading to the transcription of multiple target genes involved in innate immunity. These include chemokines, such as CXCL8 (IL-8) and CCL20, the cytokines IL-6, tumor necrosis factor alpha (TNF- $\alpha$ ), granulocyte- and granulocyte-macrophage colony-stimulating factor (G-CSF and GM-CSF, respectively), acute phase proteins such as C-reactive protein, antimicrobial peptides and mucins [88]. Thus, IL-17 plays an important role in antimicrobial defenses by recruiting and expanding the neutrophil lineage and producing antimicrobial peptides. The proinflammatory cytokines produced by Th17 cells include TNF $\alpha$, IL-22 and IL-26, which are involved in innate immunity, and IL- 6 which directs CD4+T cells differentiation towards the Th17 lineage. IL-22 has been associated with the generation of defensins, acute phase proteins and inflammatory cytokines [89]. This multidirectional, fundamental role of Th17 cells, including cells with specificities against candidal antigens explains the pattern of infection susceptibility characteristic of STAT3 mutated HIES patients. In the recent report by Conti et al [90] a decrease of salivary antimicrobial peptides, such as $\beta$-defensin 2 and Histatins has been demonstrated in AD-HIES patients, providing a mechanism for the severe susceptibility to oropharyngeal candidiasis. This finding supports this hypothesis of the crucial role of the Th17-dependent responses in immunity to Candida.

\section{Autosomal recessive HIES}

Immune assessments of DOCK 8 mutated AR-HIES patients reveal $\mathrm{T}$ cell lymphopenia with low counts of 
both CD4+ and CD8+ T cells, as well as impaired T cell expansion from activated peripheral blood mononuclear cells in vitro. In autosomal recessive HIES eosinophilia and the elevated serum IgE may be more pronounced than in AD-HIES [9]. In contrast to the latter syndrome, DOCK8 deficiency is associated with low IgM concentrations and impaired generation of a durable secondary antibody response to specific antigens, which accounts for the functional antibody abnormalities [91]. In a single patient with AR-HIES due to TYK2 mutation, a normal number of lymphocytes was observed.

\section{Principles of treatment}

The therapeutic strategy in hyper-IgE syndrome is directed mainly toward the prevention and management of infections. The introduction of regular long-term intake of systemic antibiotics and antifungal drugs is of great importance, as it can prevent serious, overwhelming infections and prevent lung parenchymal damage. In the empiric treatment of active respiratory infections, antibiotics introduced early on to cover such microorganisms as Staphylococcus aureus, Haemophilus influenzae and Streptococcus pneumoniae in their spectrum are recommended. Lung abscesses, which can occur frequently, particularly with staphylococcal pneumonia, may require surgical intervention. However, frequent complications after surgery also require particular attention. An important therapeutic problem as well concerns pneumatocele and bronchiectases, superinfected with Pseudomonas aeruginosa and other Gram negative bacteria or with fungi, such as Aspergillus fumigatus; in these cases conservative treatment is usually ineffective. Invasive procedures - resection of the lung parenchyma limited to pneumatocele or confined bronchiectases are high-risk therapeutic options due to the reduced ability of expanding the remaining portion of the lungs [7]. Therefore, in HIES, the decision over the resection of pneumatocele should be made with particular caution.

In contradistinction to atopic dermatitis in hyper-IgE syndrome, skin changes frequently improve only after antibiotic treatment [92]; therefore, intensive antibacterial and antifungal drugs are recommended in the therapeutic strategy of cutaneous lesions. Skin abscesses should be incised and drained. In exacerbations of eczema caused by the Staphylococcus aureus infection, apart from topical antibacterial treatment, emollients and corticosteroids, systemic antibiotic therapy is recommended as well. In superficial skin and mucosal candidiasis - onychomycosis, vaginomycosis and oral thrush treatment with second-generation triazole agents is effective; moreover, these drugs are also recommended in the treatment of invasive aspergillosis [93].

The use of long-term antibacterial chemotherapy, including antistaphylococcal activity in its spectrum, e.g. trimethoprime/sulfamethoxazole, semisynthetic penicillins or cephalosporins, significantly contributes to the reduction of skin abscesses and staphylococcal pneumonias $[7,94]$. The development of resistance in the course of long-term therapy outweighs the risk of severe infections and lung damage when it is discontinued [7]. The administration of immunoglobulins is controversial. Kimata et al [95] reported positive results of high-dose intravenous immunoglobulins, leading to the decrease in IgE concentration and in effective protection against severe infections. Even if the concentration of IgG is within the normal parameters for the age range, deficiency of IgG subclasses or lack of specific post-vaccination antibodies are observable. Consequently, the introduction of regular immunoglobulin substitution seems to be of great value; however, some authors did not note any positive effect in the use of this treatment [96]. In HIES some positive clinical effects [97], as well as an improvement of the neutrophil chemotactic function assessed in vitro [98], were achieved during prophylactic treatment with H2-receptor antagonists. Improvements in neutrophil phagocytosis and in respiratory burst were also noted with the use of sodium cromoglycate $[99,100]$. Poor effects of levamisole therapy reported by Donabedian [101] do not warrant its use in the case of the hyper-IgE syndrome. On the contrary, synthetic vitamin A derivative - isothretinoine proved to be effective in the treatment of cutaneous complications [102].

In vitro studies revealed an improvement in the neutrophil chemotactic function with IFN- $\gamma$ [103], yet clinical observations point to the lack of a long-term effect on IgE concentration and on episodes of infection in patients with HIES [104]. Moreover, in one patient who was on interferon therapy, autoimmune thrombocytopenia was noted [105]. Reports concerning the use of cyclosporine A are encouraging; a positive clinical effect was observed by Wolach [106] and Etzioni [107]. Ishikava et al [108] and other investigators [23,109] noted an improvement after plasmapheresis. Currently, there is a lack of data associating therapeutic benefits with monoclonal anti-IgE antibody (omalizumab); the required high dose for neutralization of immunoglobulin E appears to exclude its clinical application. Attempts at hematopoietic stem cell transplantation (HSCT) also have been undertaken. Preliminary studies did not confirm the efficacy of this procedure [110,111], albeit further reports showed successful immunologic reconstitution in patients with both autosomal dominant [112] and autosomal recessive hyper-IgE syndrome [113-115]. Particularly in the latter form of HIES due to DOCK8 deficiency, HSCT should be considered early on before the development of life-threatening complications, including malignancies [113]. 


\section{Preliminary diagnosis}

A scoring system comprising both clinical and laboratory diagnostic criteria has been proposed by Grimbacher and colleagues and accepted by the National Institute of Health (NIH) [116] (table 1). An analysis, carried out on the basis of this scale and reaching the particular total score, indicates that the affected individual is probably a carrier of the hyper-IgE genotype, or that the presence of this genotype is uncertain, or, at the very least, is less likely. However, several symptoms like scoliosis, a characteristic face, or delayed loss of primary teeth can not be taken into account in children under the age of eight, since they may not occur until adolescence. Likewise, the number of episodes with infections, bone fractures and pulmonary disorders leading to the development of pneumatocele increases with age. Therefore, in the scoring system, the age intervals of the occurrence of particular symptoms have been included. The assessment of the suspected patient according to this scoring system and the gaining $\geq 15$ points makes the recognition of hyper-IgE phenotype highly probable. The diagnostic approach proposed recently by Schimke and colleagues confirmed that the NIH scoring system accurately identifies patients with HIES [117].

\section{Genetic testing}

The majority of patients with AD-HIES have heterozygous STAT3 mutations in the DNA-binding and Src homology 2 (SH2) domains [14,15]. All mutations are hypomorphic - missense mutations or in-frame deletions - and involve only one allele of STAT3, which suggests a dominant-negative effect. However, these mutations are found only in a limited number of patients with incomplete clinical features [16,57]. This observation is supported by $\mathrm{Al}$ Khatib et al [118], indicating molecular heterogeneity of the disease and suggesting that other potential gene defects may be functionally linked to STAT3. Recently, diagnostic criteria for STAT3-deficient individuals with clinical suspicion of HIES were proposed by Woellner and colleagues [119]. The following characteristics - total IgE concentration > $1000 \mathrm{IU} / \mathrm{ml}$ and weighted score of clinical features $>30$ (based on recurrent pneumonias, newborn rash, pathologic bone fractures, characteristic face and high palate) plus a dominant-negative heterozygous mutation in STAT3 allow for a definitive diagnosis.

Homozygous mutations in $D O C K 8$, causing premature termination, frameshift, splice site disruption, single exon deletions and microdeletions were found in many, although not all, patients with autosomal recessive hyper-IgE syndrome [19]. To date, a single patient with a clinical diagnosis of AR-HIES was identified with a homozygous TYK2 gene mutation. This suggests that other genes may also result in the autosomal recessive form of HIES [18].

\section{Concluding remarks}

The hyper-IgE syndrome, a multisystemic disorder with a broad constellation of clinical manifestations, is a great challenge for clinicians in establishing a diagnosis in suspected cases. HIES seems to be not a sole disease but rather a group of similar diseases with heterogeneity of underlying genetic defects. Patients with the hyperIgE syndrome require interdisciplinary care by specialists in pediatrics/internal medicine, pneumonology, dermatology, surgery, stomatology, neurology, oncology, and psychology under the clinical immunologist's supervision.

\section{Author details}

${ }^{1}$ Department of Pediatric Pneumonology, Allergology and Clinical Immunology, Poznan University of Medical Sciences, 27/33 Szpitalna Street, 60-572 Poznan, Poland. Department of Immunology, The Children's Memorial Health Institute, 20 Dzieci Polskich Street, 04-736 Warsaw, Poland. ${ }^{3}$ Department of Pediatric Dentistry, Poznan University of Medical Sciences, 70 Bukowska Street, 60-812 Poznan, Poland.

\section{Authors' contributions}

ASzP was responsible for the intellectual concept, design of the review, acquisition of data and their analysis and was the major participant in drafting the manuscript and its revision, ZK participated in acquisition of data and helped in drafting the manuscript, BP was involved in the revision of the manuscript, EHP was involved in the revision of the manuscript, $A B$ revised critically the manuscript, KG participated in the acquisition of data and helped draft the manuscript.

All authors read and approved the final manuscript.

\section{Competing interests}

The authors declare that they have no competing interests.

Received: 6 June 2011 Accepted: 15 November 2011

Published: 15 November 2011

\section{References}

1. Davis SD, Schaller J, Wedgwood RJ: Job's syndrome: Recurrent, "cold" staphylococcal abscesses. Lancet 1966, 1:1013-1015.

2. Buckley $\mathrm{RH}$, Wray $\mathrm{BB}$, Belmarker $\mathrm{EZ}$ : Extreme hyperimmunoglobulinemia $\mathrm{E}$ and undue susceptibility to infection. Pediatrics 1972, 49:59-70.

3. Hill HR, Ochs HD, Quie PG, Clark RA, Pabst HF, Klebanoff SJ, Wedgwood RJ: Defect in neutrophil granulocyte chemotaxis in Job's syndrome of recurrent "cold" staphylococcal abscesses. Lancet 1974, 2:617-619.

4. Hill HR, Quie PG: Raised serum IgE levels and defective neutrophil chemotaxis in three children with eczema and recurrent bacterial infections. Lancet 1974, 1:183-197.

5. Buckley RH, Becker WG: Abnormalities in the regulation of human lgE synthesis. Immunol Rev 1978, 41:288-314.

6. Erlewyn-Lajeunesse MD: Hyperimmunoglobulin-E syndrome with recurrent infection: a review current opinion and treatment. Pediatr Allergy Immunol 2004, 11:133-141.

7. Grimbacher B, Holland SM, Puck JM: Hyper-IgE syndromes. Immunol Rev 2005, 203:244-250

8. Freeman AF, Holland SM: The hyper-IgE syndromes. Immunol Allergy Clin North Am 2008, 28:2777.

9. Freeman AF, Holland SM: Clinical manifestations, etiology and pathogenesis of the hyper-IgE syndromes. Pediatr Res 2009, 65:32-37.

10. Church JA, Frenkel LD, Wright DG, Bellanti JA: T lymphocyte dysfunction, hyperimmunoglobulinemia $\mathrm{E}$, recurrent bacterial infections, and 
defective neutrophil chemotaxis in a Negro child. J Pediatr 1976, 88:982-985

11. Pherwani AV, Rodrigues C, Dasgupta A, Bavdekar MA, Rao ND: Hyperimmunoglobulin E syndrome. Indian Pediatr 1994, 31:328-330.

12. Grimbacher B, Belohradsky BH, Holland SM: Immunoglobulin E in primary immunodeficiency diseases. Allergy 2002, 57:995-1007.

13. Minegishi $\mathrm{Y}$, Karasuyama $\mathrm{H}$ : Genetic origins of hyper-lgE syndrome. Curr Allergy Asthma Rep 2008, 8:386-391.

14. Minegishi $Y$, Karasuyama H: Defects in Jak-STAT-mediated cytokine signals cause hyper-lgE syndrome: lessons from a primary immunodeficiency. Int Immunol 2008, 21:105-112.

15. Renner ED, Rylaarsdam S, Anover-Sombke S, Rack AL, Reichenbach J, Carey JC, Zhu Q, Jansson AF, Barboza J, Schimke LF, Leppert MF, Getz MM, Seger RA, Hill HR, Belohradsky BH, Torgerson TR, Ochs HD: Novel signal transducer and activator of transcription 3 (STAT3) mutations, reduced $\mathrm{T}_{\mathrm{H}} 17$ cell numbers, and variably defective STAT3 phosphorylation in hyper-lgE syndrome. J Allergy Clin Immunol 2008, 122:181-187.

16. Holland SM, DeLeo FR, Elloumi HZ, Hsu AP, Uzel G, Brodsky N, Freeman AF, Demidowich AS, Davis J, Turner ML, Anderson VL, Darnell DN, Welch PA, Kuhns DB, Frucht DM, Malech HL, Gallin Jl, Kobayashi SD, Whitney AR, Voyich JM, Musser JM, Woellner C, Schaffer AA, Puck JM, Grimbacher B: STAT3 mutations in the hyper-lgE syndrome. N Engl I Med 2007, 357:1608-1619.

17. Renner ED, Puck JM, Holland SM, Schmitt M, Weiss M, Frosch M, Bergmann M, Davis J, Belohradsky BH, Grimbacher B: Autosomal recessive hyperimmunoglobulin E syndrome: a distinct disease entity. J Pediatr 2004, 144:93-99.

18. Minegishi Y, Saito M, Morio T, Watanabe K, Agematsu K, Tsuchiya S, Takada H, Hara T, Kawamura N, Ariga T, Kaneko H, Kondo N, Tsuge I, Yachie A, Sakiyama Y, Iwata T, Bessho F, Ohishi T, Joh K, Imai K, Kogawa K, Shinohara M, Fujieda M, Wakiguchi H, Pasic S, Abinun M, Ochs HD, Renner ED, Jansson A, Belohradsky BH, Metin A, Shimizu N, Mizutani S, Miyawaki T, Nonoyama S, Karasuyama H: Human tyrosine kinase 2 deficiency reveals its requisite roles in multiple cytokine signals involved in innate and acquired immunity. Immunity 2006, 25:745-755.

19. Engelhardt KR, McGhee S, Winkler S, Sassi A, Woellner C, Lopez-Herrera G, Chen A, Kim HS, Lloret MG, Schulze I, Ehl S, Thiel J, Pfeifer D, Veelken H, Niehues T, Siepermann K, Weinspach S, Reisli I, Keles S, Genel F, Kutukculer N, Camcioğlu Y, Somer A, Karakoc-Aydiner E, Barlan I, Gennery A, Metin A, Degerliyurt A, Pietrogrande MC, Yeganeh M, Baz Z, Al-Tamemi S, Klein C, Puck JM, Holland SM, McCabe ER, Grimbacher B, Chatila TA: Large deletions and point mutations involving the dedicator of cytokinesis 8 (DOCK8) in the autosomal-recessive form of hyper-lgE syndrome. J Allergy Clin Immunol 2009, 124:1289-1302.

20. Chamlin SL, McCalmont TH, Cunningham BB, Esterly NB, Lai CH, Mallory SB, Mancini AJ, Tamburro J, Frieden IJ: Cutaneous manifestations of hyper-lgE syndrome in infants and children. J Pediatr 2002, 141:572-575.

21. Eberting CL, Davis J, Puck JM, Holland SM, Turner ML: Dermatitis and the newborn rash of hyper-IgE syndrome. Arch Dermatol 2004, 140:1119-1125.

22. Buckley RH: Disorders of the IgE system. In Immunological Disorders in Infants and Children. Edited by: Stiehm ER. Philadelphia: Saunders; 1996:409-422.

23. Leung DY, Geha RS: Clinical and immunologic aspects of the hyperimmunoglobulin E syndrome. Hematol Oncol Clin North Am 1988, 2:81-100.

24. Ohameje NU, Loveless JW, Saini SS: Atopic dermatitis or hyper-lgE syndrome? Allergy Asthma Proc 2006, 27:289-291.

25. Shirafuji $Y$, Matsuura $H$, Sato A, Kanzaki $H$, Katayama $H$, Arata J: Hyperimmunoglobulin E syndrome: a sing of $\mathrm{TH} 1 / \mathrm{TH} 2$ imbalance? Eur $J$ Dermatol 1999, 9:129-131.

26. DeWitt CA, Bishop AB, Buescher LS, Stone SP: Hyperimmunoglobulin E syndrome: two cases and a review of the literature. J Am Acad Dermatol 2006, 54:855-865.

27. Jaramillo D, Kim EE: Demonstration of a cold abscess by gallium- 67 imaging in a patient with Job syndrome. ARJ Am J Roentgenol 1986, 147:610-611.

28. Sato E, Yamamoto H, Honda T, Koyama S, Kubo K, Sediguchi M: Acute respiratory distress syndrome due to methicillin-resistant Staphylococcus aureus sepsis in hyper-IgE syndrome. Eur Respir J 1996, 9:386-388.

29. Lui RC, Inculet Rl: Job's syndrome: a rare cause of recurrent lung abscess in childhood. Ann Thorac Surg 1990, 50:992-994.
30. Shamberger RC, Wohl ME, Perez-Atayde A, Hendren WH: Pneumatocele complicating hyperimmunoglobulin E syndrome (Job's Syndrome). Ann Thorac Surg 1992, 54:1206-1208.

31. Freeman AF, Kleiner DE, Nadiminti H, Davis J, Quezado M, Anderson V, Puck JM, Holland SM: Causes of death in hyper-lgE syndrome. J Allergy Clin Immunol 2007, 119:1234-1240.

32. Gorur K, Ozcan C, Unal M, Akbaş Y, Vayisoğlu Y: Hyperimmunoglobulin-E syndrome: a case with chronic ear draining mimicking polypoid otitis media. Int J Pediatr Otorhinolaryngol 2003, 67:409-412.

33. Freeman AF, Davis J, Anderson VL, Barson W, Darnell DN, Puck JM, Holland SM: Pneumocystis jiroveci infection in patients with hyperimmunoglobulin E syndrome. Pediatrics 2006, 118:1271-1275.

34. Grimbacher B, Holland SM, Gallin Jl, Greenberg F, Hill SC, Malech HL, Miller JA, O'Connell AC, Puck JM: Hyper-lgE syndrome with recurrent infections: an autosomal dominant multisystem disorder. N Eng/ J Med 1999, 340:692-702.

35. Jacobs DH, Macher AM, Handler R, Bennett JE, Collen MJ, Gallin J: Esophageal cryptococcosis in a patient with the hyperimmunoglobulin E-recurrent infection (Job's) syndrome. Gastroenterology 1984, 87:201-203.

36. Stone BD, Wheeler JG: Disseminated cryptococcal infection in a patient with hyperimmunoglobulinemia E syndrome. J Pediatr 1990, 117:92-95.

37. Alberti-Flor JJ, Granda A: lleocecal histoplasmosis mimicking Crohn's disease in a patient with Job's syndrome. Digestion 1986, 33:176-180.

38. Cappell MS, Manzione NC: Recurrent colonic histoplasmosis after standard therapy with amphotericin B in a patient with Job's syndrome. Am J Gastroenterol 1991, 86:119-120.

39. Desai K, Huston DP, Harriman GR: Previously undiagnosed hyper-IgE syndrome in an adult with multiple systemic fungal infections. J Allergy Clin Immunol 1996, 98:1123-1124.

40. Yilmaz E: Disseminated pulmonary candidiasis complicating hyperimmunoglobulin E (Job's) syndrome. J Thorac Imaging 2004, 19:48-51.

41. Pasic S: Local bacillus Calmette-Guerin infection in hyperimmunoglobulin-E syndrome. Acta Pediatr 2002, 91:1271-1272.

42. Pasic S, Lilic D, Pejnovic N, Vojvodic D, Simic R, Abinun M: Disseminated Bacillus Calmette-Guerin infection in a girl with hyperimmunoglobulin $\mathrm{E}$ syndrome. Acta Pediatr 1998, 87:702-704.

43. Hershko K, Hershko AY, Leibovici V, Meir K, Ingber A: Herpes simplex virus infection in a hyper-lgE patient: appearance of unusual mass lesions. Acta Derm Venerol 2002, 82:204-205.

44. Borges WG, Hensley T, Carey JC, Petrak BA, Hill HR: The face of Job. J Pediatr 1998, 133:303-305.

45. Donabedian H, Gallin J: The hyperimmunoglobulin E recurrent-infection (Job's) syndrome. A review of the $\mathrm{NIH}$ experience and the literature. Medicine (Baltimore) 1983, 62:195-208

46. Gahr M, Müller W, Allgeier B, Speer CP: A boy with recurrent infections, impaired PMN-chemotaxis, increased IgE concentrations and cranial synostosis - a variant of the hyper-IgE syndrome? Helv Paediatr Acta 1987, 42:185-190.

47. Höger PH, Boltshauser $E$, Hitzig WH: Craniosynostosis in hyper-IgE syndrome. Eur J Pediatr 1995, 144:414-417.

48. Smithwick EM, Finelt M, Pahwa S: Cranial synostosis in Job's syndrome. Lancet 1978, 1:826.

49. O'Connell AC, Puck JM, Grimbacher B, Facchetti F, Majorana A, Gallin Jl, Malech HL, Holland SM: Delayed eruption of permanent teeth in hyperimmunoglobulinemia E recurrent infection syndrome. Oral Surg Oral Med Oral Pathol Oral Radiol Endod 2000, 89:177-185.

50. Vigiliante CE, Costello BJ, Quinn PD: Life-threatening cervicofacial infection in a child with hyperimmunoglobulin-E syndrome. J Oral Maxillofac Surg 2001, 59:561-565.

51. Tsang P, Derkson G, Priddy R, Junker AK, Slots J, Larjava H: Severe periodontitis in a 5-year old girl with hyperimmunoglobulin E syndrome. Pediatr Dent 2005, 27:68-73.

52. Kirchner SG, Sivit CJ, Wright PF: Hyperimmunoglobulinemia E syndrome: association with osteoporosis and recurrent fractures. Radiology 1985, 156:362.

53. Brestel EP, Klingberg WG, Veltri RW, Dorn JS: Osteogenesis imperfecta tarda in a child with hyper-lgE syndrome. Am J Dis Child 1982, 136:774-776

54. Lallemand D, Kalifa G, Buriot D, Sauvegrain J, Griscelli C: Constitutional bone anomalies in congenital immune deficiences. Ann Radiol (Paris) 1979, 22:108-118. 
55. Leung DY, Key L, Steinberg JJ, Young MC, Von Deck M, Wilkinson R, Geha RS: Increased in vitro bone resorption by monocytes in the hyperimmuno-globulin E syndrome. J Immunol 1988, 140:84-88.

56. Cohen-Solal M, Prieur AM, Prin L, Denne MA, Launay JM, Graulet AM, Brazier M, Griscelli C, de Vernejoul MC: Cytokine-mediated bone resorption in patients with the hyperimmunoglobulin $\mathrm{E}$ syndrome. Clin Immunol Immunopathol 1995, 76:75-81.

57. Minegishi Y, Saito M, Tsuchiya S, Tsuge I, Takada H, Hara T, Kawamura N, Ariga T, Pasic S, Stojkovic O, Metin A, Karasuyama H: Dominant-negative mutations in the DNA-binding domain of STAT3 cause hyper-lgE syndrome. Nature 2007, 448:1058-1062.

58. Lee MW, Choi JH, Sung KJ, Moon KC, Koh JK: Extensive xanthelasma associated with anaplastic large cell lymphoma and

hyperimmunoglobulin E syndrome. Int J Dermatol 2003, 42:944-94.

59. Crama N, Toolens AM, van der Meer JW, Cruysberg JR: Giant chalazia in the hyperimmunoglobulinemia E (hyper-lgE) syndrome. Eur J Ophthalmol 2004, 14:258-260.

60. Patteri $P$, Serru A, Chessa ML, Loi M, Pinna A: Recurrent giant chalazia in hyperimmunoglobulin E (Job's) syndrome. Int Ophthalmol 2009, 29:415-417.

61. Shemer A, Weiss G, Confino Y, Trau H: The hyper-lgE syndrome. Two cases and review of the literature. Int J Dermatol 2001, 40:622-628.

62. Orhan M, Ozkan $Y$, Irkec M: Eye involvement in hyperimmunoglobulinemia E (Job's) syndrome. J Pediatr Ophthalmol Strabismus 2001, 38:313-314.

63. Arora V, Kim UR, Khazei HM, Kusagur S: Ophthalmic complications including retinal detachment in hyperimmunoglobulinemia $\mathrm{E}$ (Job's) syndrome: Case report and review of literature. Indian J Ophthalmol 2009, 57:385-386.

64. Brugnoni D, Franceschini F, Airò P, Cattaneo R: Discordance for systemic lupus erythematosus and hyper IgE syndrome in a pair of monozygotic twins. Br J Rheumatol 1998, 37:807-808.

65. North J, Kotecha S, Houtman P, Whaley K: Systemic lupus erythematosus complicating hyper lgE syndrome. Br J Rheumatol 1997, 36:297-298.

66. Schopfer K, Baerlocher K, Price P, Krech U, Quie PG, Douglas SD Staphylococcal IgE antibodies, hyperimmunoglobulinemia $\mathrm{E}$ and Staphylococcus aureus infections. N Engl J Med 1979, 300:835-838.

67. Min JK, Cho ML, Kim SC, Lee YS, Lee SH, Park SH, Hong YS, Cho CS, Kim HY: Hyperimmunoglobulin E-recurrent infection syndrome in a patient with juvenile dermatomyositis. Korean J Intern Med 1999 14:95-98.

68. Tanji C, Yorioka N, Kanahara K, Naito T, Oda H, Ishikawa K, Taguchi T: Hyperimmunoglobulin E syndrome associated with nephrotic syndrome. Intern Med 1999, 38:491-494.

69. Bale JF Jr, Wilson JF, Hill HR: Fatal histiocytic lymphoma of the brain associated with hyperimmunoglobulinemia-E and recurrent infections. Cancer 1977, 39:2386-2390.

70. Chang SE, Huh J, Choi JH, Sung K, Moon KC, Koh JK: A case of hyper-lgE syndrome complicated by cutaneous, nodal, and liver peripheral T cell lymphomas. J Dermatol 2002, 29:320-322.

71. Leonard GD, Posadas E, Herrmann PC, Anderson VL, Jaffe ES, Holland SM, Wilson WH: Non-Hodgkin's lymphoma in Job's syndrome: a case report and literature review. Leuk Lymphoma 2004, 45:2521-2525.

72. Onal IK, Kurt M, Altundag K, Aksoy S, Dincer M, Gullu I: Peripheral T-cell lymphoma and Job's syndrome: a rare association. Med Oncol 2006, 23:141-144.

73. Kashef MA, Kashef S, Handjani F, Karimi M: Hodgkin lymphoma developing in a 4.5-year-old girl with hyper-lgE syndrome. Pediatr Hematol Oncol 2006, 23:59-63.

74. Lin SJ, Huang JL, Hsieh KH: Hodgkin's disease in a child with hyperimmunoglobulin E syndrome. Pediatr Hematol Oncol 1988, 15:451-454.

75. Oztop I, Demirkan B, Tarhan O, Kayahan H, Yilmaz U, Kargi A, Alakavuklar M: The development of pulmonary adenocarcinoma in a patient with Job's syndrome, a rare immunodeficiency condition. Tumori 2004, 90:132-135.

76. Ling JC, Freeman AF, Gharib AM, Arai AE, Lederman RJ, Rosing DR, Holland SM: Coronary artery aneurysms in patients with hyper $\lg E$ recurrent infection syndrome. Clin Immunol 2007, 122:255-258.

77. Yavuz H, Chee R: A review on the vascular features of the hyperimmunoglobulin E syndrome. Clin Exp Immunol 2010, 159:238-244.
78. Freeman AF, Avila EM, Shaw PA, Davis J, Hsu AP, Weich P, Matta JR, Hadigan C, Pettigrew RI, Holland SM, Gharib AM: Coronary artery abnormalities in hyper-IgE syndrome. J Clin Immunol 2011, 31:338-345.

79. Zhang Q, Davis JC, Dove CG, Su HC: Genetic, clinical, and laboratory markers for DOCK8 immunodeficiency syndrome. Dis Markers 2010, 29:131-139.

80. Zhang $\mathrm{Q}$, Davis JC, Lamborn IT, Freeman AF, Jing H, Favreau AJ, Matthews HF, Davis J, Turner ML, Uzel G, Holland SM, Su HC: Combined immunodeficiency associated with DOCK8 mutations. N Engl J Med 2009, 361:2016-2055

81. Muhammed K: Hyper IgE syndrome: report of two cases with moderate elevation of IgE. Indian J Dermatol Venereol Leprol 2005, 71:112-114.

82. Berger M, Kirkpatrick CH, Goldsmith PK, Gallin Jl: IgE antibodies to Staphylococcus aureus and Candida albicans in patients with the syndrome of hyperimmunoglobulin $\mathrm{E}$ and recurrent infections. J Immunol 1990, 125:2437-2443.

83. Schopfer K, Feldges A, Baerlocher K, Parisot RF, Wilhelm JA, Matter L: Systemic lupus erythematosus in Staphylococcus aureus hyperimmunoglobulinaemia E syndrome. Br Med J (Clin Res Ed) 1983, 287:524-526.

84. Lavoie A, Rottem M, Grodofsky MP, Douglas SD: Anti-Staphylococcus aureus IgE antibodies for diagnosis of hyperimmunoglobulinemia $\mathrm{E}$ recurrent infection syndrome in infancy. Am J Dis Child 1989, 143:1038-1041

85. Walsh GA, Richards KL, Douglas SD, Blumenthal MN: Immunoglobulin E anti-Staphylococcus aureus antibodies in atopic patients. J Clin Microbiol 1981, 13:1046-1048.

86. Buckley RH: The hyper-IgE syndrome. Clin Rev Allergy Immunol 2001, 20:139-154.

87. Milner JD, Brenchley JM, Laurence A, Freeman AF, Hill BJ, Elias KM, Kanno Y, Spalding C, Elloumi HZ, Paulson ML, Davis J, Hsu A, Asher Al, O'Shea J, Holland SM, Paul WE, Douek DC: Impaired $T_{H} 17$ cell differentiation in subjects with autosomal dominant hyper-IgE syndrome. Nature 2008, 452:773-776.

88. Gaffen SL: An overview of IL-17 function and signaling. Cytokine 2008, 43:402-407.

89. Ochs HD, Oukka M, Torgerson TR: TH17 cells and regulatory T cells in primary immunodeficiency diseases. J Allergy Clin Immunol 2009, 123:977-983.

90. Conti HR, Baker O, Freeman AF, Jang WS, Holland SM, Li RA, Edgerton M, Gaffen SL: New mechanism of oral immunity to mucosal candidiasis in hyper-IgE syndrome. Mucosal Immunol 2011, 4:448-455.

91. Su HC: Dedicator of cytokinesis 8 (DOCK8) deficiency. Curr Opin Allergy Clin Immunol 2010, 10:515-520.

92. Hochreutener $H$, Wüthrich B, Huwyler $T$, Schopfer $K$, Seger R, Baerlocher K: Variant of hyper-IgE syndrome: the differentiation from atopic dermatitis is important because of treatment and prognosis. Dermatologica 1991, 182:7-11.

93. Johnson MD, Perfect JR: Use of Antifungal Combination Therapy: Agents, Order, and Timing. Curr Fungal Infect Rep 2010, 4:87-95.

94. Tanaka H, Ito R, Onodera N, Waga S: Efficacy of long-term sulfamethoxazole-trimethoprim therapy in a boy with hyperimmunoglobulin E syndrome. Tohoku J Exp Med 1998, 186:61-66.

95. Kimata $\mathrm{H}$ : High-dose intravenous gamma-globulin treatment for hyperimmunoglobulinemia E syndrome. J Allergy Clin Immunol 1995, 95:771-774.

96. Wakim M, Alazard M, Yajima A, Speights D, Saxon A, Stiehm ER: High-dose intravenous immunoglobulin in atopic dermatitis and hyper-lgE syndrome. Ann Allergy Asthma Immunol 1998, 81:153-158.

97. Thompson RA, Kumararatne DS: Hyper-IgE syndrome and $\mathrm{H} 2$ - receptor blockade. Lancet 1989, 2:630

98. Mawhinney $H$, Killen M, Fleming WA, Roy AD: The hyperimmunoglobulin $E$ syndrome - a neutrophil chemotactic defect reversible by histamine $\mathrm{H} 2$ receptor blockade? Clin Immunol Immunopathol 1980, 17:483-491.

99. Kojima K, Inoue Y, Katayama Y, Kataoka M, Sunami K, Fukuda S, Sezaki T, Omoto $E$, Harada M: Improvement with disodium cromoglycate of neutrophil phagocytosis and respiratory burst activity in a patient with hyperimmunoglobulin E syndrome. Allergy 1998, 53:1101-1103.

100. Yokota S, Mitsuda T, Shimizu H, Ibe M, Ikezawa Z: Cromoglycate treatment of a patient with hyperimmunoglobulinemia E syndrome. Lancet 1990, 335:857-858 
101. Donabedian H, Alling DW, Gallin Jl: Levamisole is inferior to placebo in the hyperimmunoglobulin E recurrent-infection (Job's) syndrome. N Engl J Med 1982, 307:290-292.

102. Shuttleworth D, Holt PJ, Mathews N: Hyperimmunoglobulin E syndrome: treatment with isotretinoin. Br J Dermatol 1988, 119:93-99.

103. Jeppson JD, Jaffe HS, Hill HR: Use of recombinant human interferon gamma to enhance neutrophil chemotactic responses in Job syndrome of hyperimmunoglobulinemia $\mathrm{E}$ and recurrent infections. J Pediatr 1991, 118:383-387.

104. King CL, Gallin JI, Malech HL, Abramson SL, Nutman TB: Regulation of immunoglobulin production in hyperimmunoglobulin $\mathrm{E}$ recurrentinfection syndrome by interferon gamma. Proc Natl Acad Sci USA 1989, 86:10085-10089

105. Aihara Y, Mori M, Katakura S, Yokota S: Recombinant IFN-gamma treatment of a patient with hyperimmunoglobulin $\mathrm{E}$ syndrome triggered autoimmune thrombocytopenia. J Interferon Cytokine Res 1998, 18:561-563.

106. Wolach B, Eliakim A, Pomeranz A, Cohen AH, Nusbacher J, Metzker A: Cyclosporin treatment of hyperimmunoglobulin $\mathrm{E}$ syndrome. Lancet 1996, 347:67.

107. Etzioni A, Shehadeh N, Brecher A, Yorman S, Pollack S: Cyclosporin A in hyperimmunoglobulin E syndrome. Ann Allergy Asthma Immunol 1997 78:413-414.

108. Ishikawa I, Fukuda Y, Kitada H, Yuri T, Shinoda A, Tani Y: Plasma exchange in a patient with hyper-lgE syndrome. Ann Allergy 1982, 49:295-297.

109. Dau PC: Remission of hyper-lgE syndrome treated with plasmapheresis and cytotoxic immunosupression. J Clin Apher 1988, 4:8-12.

110. Gennery AR, Flood TJ, Abinun M, Cant AJ: Bone marrow transplantation does not correct the hyper IgE syndrome. Bone Marrow Transplant 2000, 25:1303-1305.

111. Nester TA, Wagnon AH, Reilly WF, Spitzer G, Kjeldsberg CR, Hill HR: Effects of allogeneic peripheral stem cell transplantation in a patient with Job syndrome of hyperimmunoglobulinemia $\mathrm{E}$ and recurrent infections. Am J Med 1998, 105:162-164

112. Goussetis E, Peristeri I, Kitra V, Traeger-Synodinos J, Theodosaki M, Psarra K, Kanariou M, Tzortzatou-Stathopoulou F, Petrakou E, Fylaktou I, Kanavakis E, Graphakos S: Successful long-term immunologic reconstitution by allogeneic hematopoietic stem cell transplantation cures patients with autosomal dominant hyper-IgE syndrome. J Allergy Clin Immunol 2010, 126:392-394

113. Gatz SA, Benninghoff $U$, Schütz $C$, Schulz A, Hönig M, Pannicke $U$, Holzmann KH, Schwarz K, Friedrich W: Curative treatment of autosomalrecessive hyper-IgE syndrome by hematopoietic cell transplantation. Bone Marrow Transplant 2011, 46:552-556.

114. Bittner TC, Pannicke U, Renner ED, Notheis G, Hoffmann F, Belohradsky BH, Wintergerst U, Hauser M, Klein B, Schwarz K, Schmid I, Albert MH: Successful long-term correction of autosomal recessive hyper-lgE syndrome due to DOCK8 deficiency by hematopoietic stem cell transplantation. Klin Padiatr 2010, 222:351-355.

115. McDonald DR, Massaad MJ, Johnston A, Keles S, Chatila T, Geha RS, Pai SY: Successful engraftment of donor marrow after allogeneic hematopoietic cell transplantation in autosomal-recessive hyper-lgE syndrome caused by dedicator of cytokinesis 8 deficiency. J Allergy Clin Immunol 2010, 126:1304-1305.

116. Grimbacher B, Schäffer AA, Holland SM, Davis J, Gallin Jl, Malech HL, Atkinson TP, Belohradsky BH, Buckley RH, Cossu F, Español T, Garty BZ, Matamoros N, Myers LA, Nelson RP, Ochs HD, Renner ED, Wellinghausen N, Puck JM: Genetic linkage of hyper-IgE syndrome to chromosome 4. Am J Hum Genet 1999, 65:735-744

117. Schimke LF, Sawalle-Belohradsky J, Roesler J, Wollenberg A, Rack A, Borte M, Rieber N, Cremer R, Maass E, Dopfer R, Reichenbach J, Wahn V, Hoenig M, Jansson AF, Roesen-Wolff A, Schaub B, Seger R, Hill HR, Ochs HD, Torgerson TR, Belohradsky BH, Renner ED: Diagnostic approach to the hyper-lgE syndromes: immunologic and clinical key findings to differentiate hyper-IgE syndromes from atopic dermatitis. J Allergy Clin Immunol 2010, 126:611-617.

118. Al Khatib S, Keles S, Garcia-Lloret M, Karakoc-Aydiner E, Reisli I, Artac H, Camcioglu Y, Cokugras H, Somer A, Kutukculer N, Yilmaz M, Ikinciogullari A, Yegin O, Yüksek M, Genel F, Kucukosmanoglu E, Baki A, Bahceciler NN, Rambhatla A, Nickerson DW, McGhee S, Barlan IB, Chatila T: Defects along the $T_{H} 17$ differentiation pathway underlie genetically distinct forms of the hyper-IgE syndrome. J Allergy Clin Immunol 2009, 124:342-348.
119. Woellner C, Gertz EM, Schaeffer AA, Lagos M, Perro M, Glocker EO, Pietrogrande MC, Cossu F, Franco JL, Matamoros N, Pietrucha B, Heropolitańska-Pliszka E, Yeganeh M, Moin M, Español T, Ehl S, Gennery AR, Abinun M, Breborowicz A, Niehues T, Kilic SS, Junker A, Turvey SE, Plebani A, Sánchez B, Garty BZ, Pignata C, Cancrini C, Litzman J, Sanal O, Baumann U, Bacchetta R, Hsu AP, Davis JN, Hammarström L, Davies EG, Eren E, Arkwright PD, Moilanen JS, Viemann D, Khan S, Maródi L, Cant AJ, Freeman AF, Puck JM, Holland SM, Grimbacher B: Mutations in STAT3 and diagnostic guidelines for hyper-lgE syndrome. J Allergy Clin Immunol 2010, 125:424-432.

doi:10.1186/1750-1172-6-76

Cite this article as: Szczawinska-Poplonyk et al:: The hyperimmunoglobulin E syndrome - clinical manifestation diversity in primary immune deficiency. Orphanet Journal of Rare Diseases 2011 6:76.

\section{Submit your next manuscript to BioMed Central and take full advantage of:}

- Convenient online submission

- Thorough peer review

- No space constraints or color figure charges

- Immediate publication on acceptance

- Inclusion in PubMed, CAS, Scopus and Google Scholar

- Research which is freely available for redistribution

Submit your manuscript at www.biomedcentral.com/submit
C) Biomed Central 